\title{
Response of grey slug to entomopathogenic nematodes
}

\author{
Ayatollah Saeedizadeh ${ }^{1, *}(\mathbb{D})$, Fahimeh Niasti1(i) \\ 1. Shahed University - Department of Plant Protection - Tehran, Iran.
}

\begin{abstract}
Biological control using entomopathogenic nematodes (EPNs) is known as an ecofriendly strategy in integrated pest management. The terrestrial slug Parmacella ibera is a major pest of vegetables and citrus trees in north of Iran. The heavy costs and environmental concerns of synthetic molluscicides led the study to use EPNs, against the slug P. ibera. The present study was arranged to evaluate and compare the performance of EPNs, Steinernema feltiae, S. carpocapsae and Heterorhabditis bacteriophora on P. ibera population (mortality rate) and the feeding rate in vitro, and also its damage (seedlings establishment rate) in vitro. Phasmarhabditis hermaphrodita, as a slug parasite nematode, and also the metaldehyde, as a molluscicide, were used as positive controls. The results of the study showed that the highest mortality rate (\%) and the seedlings establishment rate (\%) of the slug population were observed in S. carpocapsae, S. feltiae and H. bacteriophora treatments, respectively. The feeding rate (\%) of the slug declined in the treatments with $H$. bacteriophora, S. feltiae and $S$. carpocapsae, respectively. The mortality rate of the pest was enhanced by extending the exposure time and increasing levels of the nematodes. Therefore, it can be concluded that the EPNs S. carpocapsae, S. feltiae and H. bacteriophora are able to control the slug P. ibera population.
\end{abstract}

Key words: biological control, Parmacella ibera, Steinernema feltiae, Steinernema carpocapsae, Heterorhabditis bacteriophora.
Received:

Mar. 17, 2020

Accepted:

Jul. 21, 2020

Section Editor:

Luis Garrigós Leite

${ }^{\star}$ Corresponding author: ayatsaeed314@gmail.com

\section{INTRODUCTION}

Terrestrial slugs have caused considerable economic losses on a variety of crops in vast lands, greenhouses and domestic gardens. Especially, they are significantly found in wet weather conditions (Wilson and Barker 2011; Watts 2012). The grey slug, Parmacella ibera Eichwald (Parmacelliade: Gastropoda), is one of the most important species of the pest molluscs in Iran. In terms of population and damage rate, this pest is a dominant species of slugs in the northern regions of the country (Yakhchali et al. 2013). In these areas, the highest slug damage has been observed on herbaceous plants from vegetables such as lettuce, cabbage, spinach and beans, as well as citrus trees (Wilson and Barker 2010).

The increase in the population of slugs and their heavy damage has encouraged many producers to apply chemical pest control. The inefficient outcomes of chemical pesticides and population reduction of natural enemies as well as dense weeds can cause an increase in slug populations (Wilson and Barker 2010). Using metaldehyde, methiocarb or chelated iron phosphate compounds in the form of poisonous bait pellets is the most common method for controlling the terrestrial molluscs pests, including slugs (Castle et al. 2017). Although the use of synthetic molluscicides has been effective in preventing the increase in the density and distribution of slug populations; however, their excessive usage can cause undesirable effects to nontarget organisms as well as irreparable environmental damages (Al-Sarar et al. 2012). Biopesticides have advantages over chemical pesticides, most notably for their safety for nontarget organisms. Also, biological products are safe for natural environments; in addition, biological control agents are readily reproducible in industrial and laboratory conditions and can be marketed (Damalas and Koutroubas 2018). 
Slugs are infected or hunted by a large number of organisms (Foltan 2004). Several species of rhabditids have been introduced as parasites of slugs; some of them have been replaced by metaldehyde in organic agriculture. The slug parasite nematode (SPN) Phasmarhabditis hermaphrodita Schneider (Rhabditidae: Rhabditida) is one of the mollusc parasites used as a biocontrol agent for pests in fields and greenhouses in Europe and the United States (De Ley et al. 2014). Other species of rhabditids, entomopathogenic nematodes (EPNs), specially Steinernema feltiae Filipjev, S. carpocapsae Weiser (Steinernematidae: Rhabditida) and Heterorhabditis bacteriophora Poinar (Heterorhabditidae: Rhabditida), have been used as biological agents to control the population of some pests in greenhouses, small farms and gardens (Zolfagharian et al. 2016; Abd-elgawad et al. 2017; Azarnia et al. 2018).

Whether EPNs can parasitize on slugs is not completely clear. In recent years, slug populations have raised through environmental considerations, reducing soil tillage, cultivation of winter crops, and reducing the tendency to use pesticides in northern regions of Iran. Therefore, applying sustainable methods to control invasive slug populations seems to be necessary. The current study was aimed to evaluate the suppression potential of EPNs, S. feltiae, S. carpocapsae and H. bacteriophora on the population of $P$. ibera. The studied traits were the mortality rate of the slug population, and the feeding rate and its damage to plants under the treatments of the EPNs in vitro.

\section{MATERIAL AND METHODS}

\section{Pest sampling}

Parmacella ibera adults (with 4-4.5 g live body weight) were collected beneath fallen leaves mass, and inside soil cavities of vegetable fields and citrus nursery in Niyasteh $\left(36^{\circ} 86^{\prime} \mathrm{N}, 50^{\circ} 74^{\prime} \mathrm{E}, 1 \mathrm{~m}\right.$ average altitude from sea level), Ramsar, Iran, in May 2018. The slugs were kept and were fed individually in glass containers to ensure the absence of any natural nematodeinfection in a growth chamber at $18{ }^{\circ} \mathrm{C}, 70 \%$ of relative humidity, and $12 \mathrm{~L}: 12 \mathrm{D}$ h photoperiods) for two weeks.

\section{Nematodes inoculums}

Strains of the EPNs H. bacteriophora (Larvanem), S. carpocapsae (Capsanem) and S. feltiae (Entanem), all prepared from Koppert B.V. (Berkel en Rodenrijs, The Netherlands), were reared on last-instar larvae of greater wax moth, Galleria melonella L., according to Dutky et al. (1964). The initial population of G. melonella was collected from bee hives in Damavand, Iran. The larvae of the insect were reared in metal net-closed ( $45 \mathrm{mesh}$ ) containers (with $2 \mathrm{~L}$ of volume) in a growth chamber $\left(27^{\circ} \mathrm{C}, 70 \% \mathrm{RH}\right.$, and $12 \mathrm{~L}: 12 \mathrm{D} \mathrm{h}$ photoperiods). The diet of the larvae was a mixture consisting of wheat flour ( $\left.120 \mathrm{~g}\right)$, yeast extract (100 g), wheat bran (260 g), wax (120 g), honey (150 mL), glycerin (200 mL), and water (50 mL) (Birah et al. 2008). According to the white trap method, infectious juveniles (IJs) of the EPNs were harvested at $15{ }^{\circ} \mathrm{C}$ within two weeks of emerging from the insect cadavers (White 1927). A stock suspension containing the IJs population of the nematodes was kept in vials containing 3-5 $\mathrm{mL}$ of distilled water and sterilized sponge at $5{ }^{\circ} \mathrm{C}$ for 2 weeks before use (Zolfagharian et al. 2016).

The SPN P. hermaphrodita (Nemaslug) prepared from BASF Agricultural Specialties Ltd (Littlehampton, UK) was reared on cadavers of field-collected $P$. ibera adult slugs. Initially, to remove any natural nematode-infestation, the slug cadavers were immersed in hot water $\left(\approx 80^{\circ} \mathrm{C}\right)$ for $10 \mathrm{~min}$. The cadavers were placed in modified white traps at $15^{\circ} \mathrm{C}$, and the emerged IJs were collected in 3-5 $\mathrm{mL}$ of distilled water, and were stored at $5{ }^{\circ} \mathrm{C}$ for two weeks before use. According to the microscopic observations, $>95 \%$ population of the emerged IJs was viable in the assays (Wilson et al. 2012).

\section{Entomopathogenic nematodes assay}

A bioassay was arranged to evaluate the feeding and mortality of $P$. ibera in response to the EPNs. The test unit included a container $(50 \times 50 \times 5 \mathrm{~cm}$ depth) including a sterile filter paper moistened with $5 \mathrm{~mL}$ of sterile distilled water, a dose level of control agent (nematode or metaldehyde), $20 \mathrm{~g}$ of fresh lettuce leaves, and 10 adult slugs. The used doses of the 
nematodes (EPNs and SPN) included 250, 500, 1000, 2000 and $4000 \mathrm{IJs} \cdot \mathrm{m}^{-2}$ (or 62, 125, 250, 500 and $1000 \mathrm{IJs} \cdot$ container $^{-1}$ ). The metaldehyde pellet (Metalan G, Bait 5\%) as the molluscicide was applied at doses of 1, 2, 4, 8, and $16 \mathrm{~g} \cdot \mathrm{m}^{-2}$ (or 0.25 , $0.5,1,2$, and $4 \mathrm{~g} \cdot$ container $\left.^{-1}\right)$. The SPN P. hermaphrodita and the molluscicide were used as positive controls.

The levels were determined based on the primary test according to the recommended ratio for the dose of nematodes and pesticide. Dosages of the nematodes as a suspension of IJs in $5 \mathrm{~mL}$ of distilled sterilized water were transferred uniformly into containers. Negative control containers were moistened with $5 \mathrm{~mL}$ of distilled water alone. The containers were sealed with metal net (10 mesh), and were incubated in a growth chamber $\left(18{ }^{\circ} \mathrm{C}, 70 \% \mathrm{RH}\right.$, and $12 \mathrm{~L}: 12 \mathrm{D}$ h photoperiods). The feeding and mortality rate (\%) of the pest were daily measured until the 9th day (as exposure times) after starting the bioassay. The remaining leaves are eaten by the slugs, thus after weighing, they were replaced daily with $20 \mathrm{~g}$ of fresh leaves (Kozłowski et al. 2011). The assay was performed with five replicates twice.

\section{Seedlings establishment assay}

To evaluate the damage or grazing incidence of the slug, established seedlings (\%) as an indicator was determined in a container experiment. Fifty-five germinated bean seeds (Phaseolus vulgaris L. cultivar Sunray) were sown in a plastic container $(50 \times 50 \times 10 \mathrm{~cm}$ depth $)$ filled with a steam-sterile sandy soil. The levels of the IJ nematodes and the pesticide were applied on the surface soil, according to defined treatments in the EPNs assay. Then, five adult slugs were transferred to each container, and the containers were sealed with metal net (10 mesh). In this assay, the containers free of the slug and the control agents was considered as a positive control. Also, a treatment including the slug and without the control agents was conducted as a negative control. The containers were transferred in a growth chamber $\left(27^{\circ} \mathrm{C}, 70 \% \mathrm{RH}\right.$, and $12 \mathrm{~L}: 12 \mathrm{D} \mathrm{h}$ photoperiods). The established seedlings rate (\%) was determined at 2, 4, 6, 8, 10, and 12 days after cultivation, as exposure times. The seedlings were sufficiently irrigated (Wilson et al. 2012). The assay was performed with five replicates twice.

\section{Statistical analysis}

A factorial experiment was conducted based on a completely randomized design (CRD) with five replicates in controlled conditions. One-way ANOVA was used for analysis of variance, and the comparison between the mean of treatments was carried out using the Tukey's test at a probability level of 5\% with SAS software. The experiment was performed twice.

\section{RESULTS}

The results of the EPNs assay showed that the mortality rate of $P$. ibera population under EPNs, S. feltiae, S. carpocapsae and $H$. bacteriophora treatments was significantly $(\mathrm{p}<0.05)$ higher than control at dose levels and exposure times. The highest dead population (\%) of the slug was observed in metaldehyde, P. hermaphrodita, S. carpocapsae, S. feltiae and H. bacteriophora treatments, respectively. Increasing the dose level and exposure time resulted in an increase in mortality rate. At the highest dose, full mortality (100\%) was observed in metaldehyde, P. hermaphrodita, S. carpocapsae, S. feltiae and H. bacteriophora treatments at 2nd, 3rd, 4th, 5th and 8th days of exposure times, respectively. The dead population was equal to 86, 67, 55, 52 , and $30 \%$ on the first day of exposure times and at highest dose level of metaldehyde, P. hermaphrodita, S. carpocapsae, S. feltiae and H. bacteriophora, respectively. The mortality rates were equal to $100,93,73,50$ and $23 \%$, respectively in metaldehyde, P. hermaphrodita, S. carpocapsae, S. feltiae and H. bacteriophora treatments at the lowest dose level and 9th day of exposure time (Fig. 1).

Also, the slugs' feeding rate $(\%)$ significantly $(\mathrm{p}<0.05)$ decreased under EPNs treatments. This was more evident in metaldehyde, $P$. hermaphrodita, S. carpocapsae, $S$. feltiae and H. bacteriophora treatments, respectively. Stop feeding completely or the feeding rate of zero or close to zero was observed in metaldehyde, $P$. hermaphrodita, $S$. carpocapsae, S. feltiae and H. bacteriophora treatments at dose IV (day 1), dose V (day 2), dose V (day 4), dose IV (day 5) and dose V (day 6), respectively (Fig. 2). 
(a)
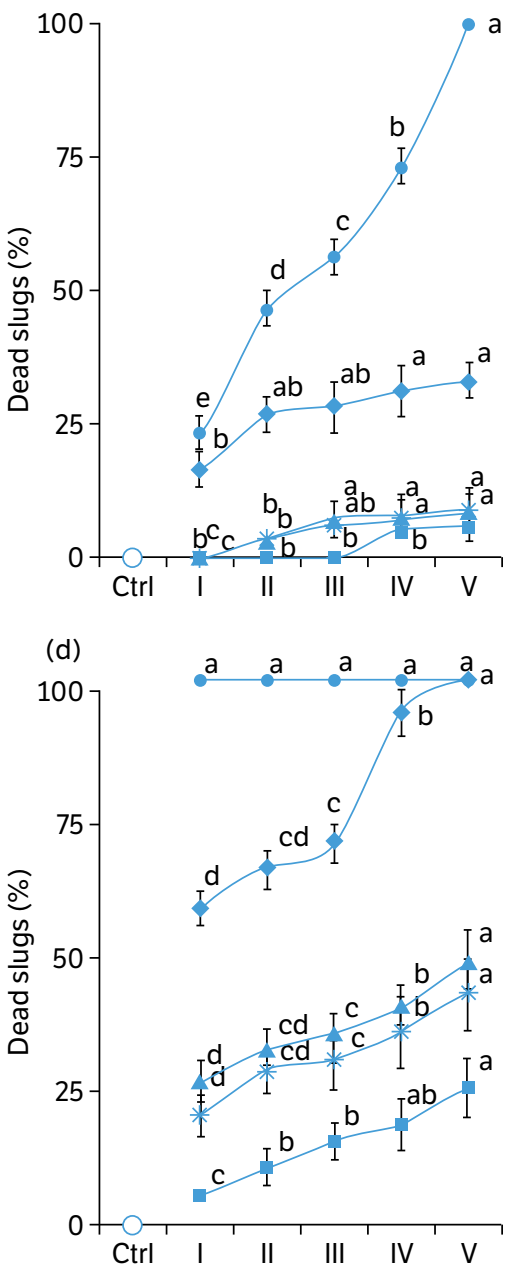

(b)

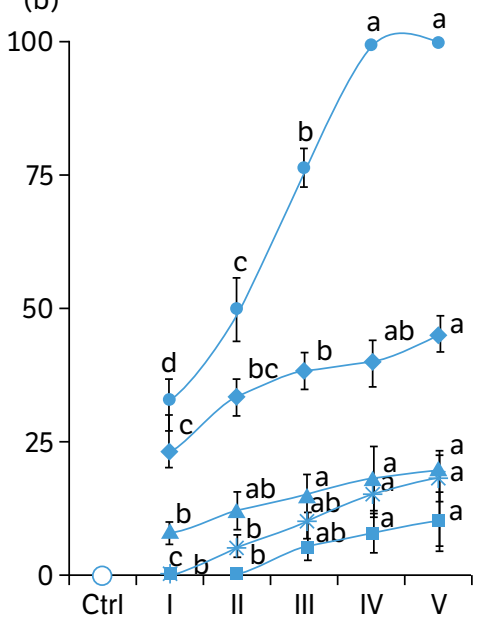

(e)
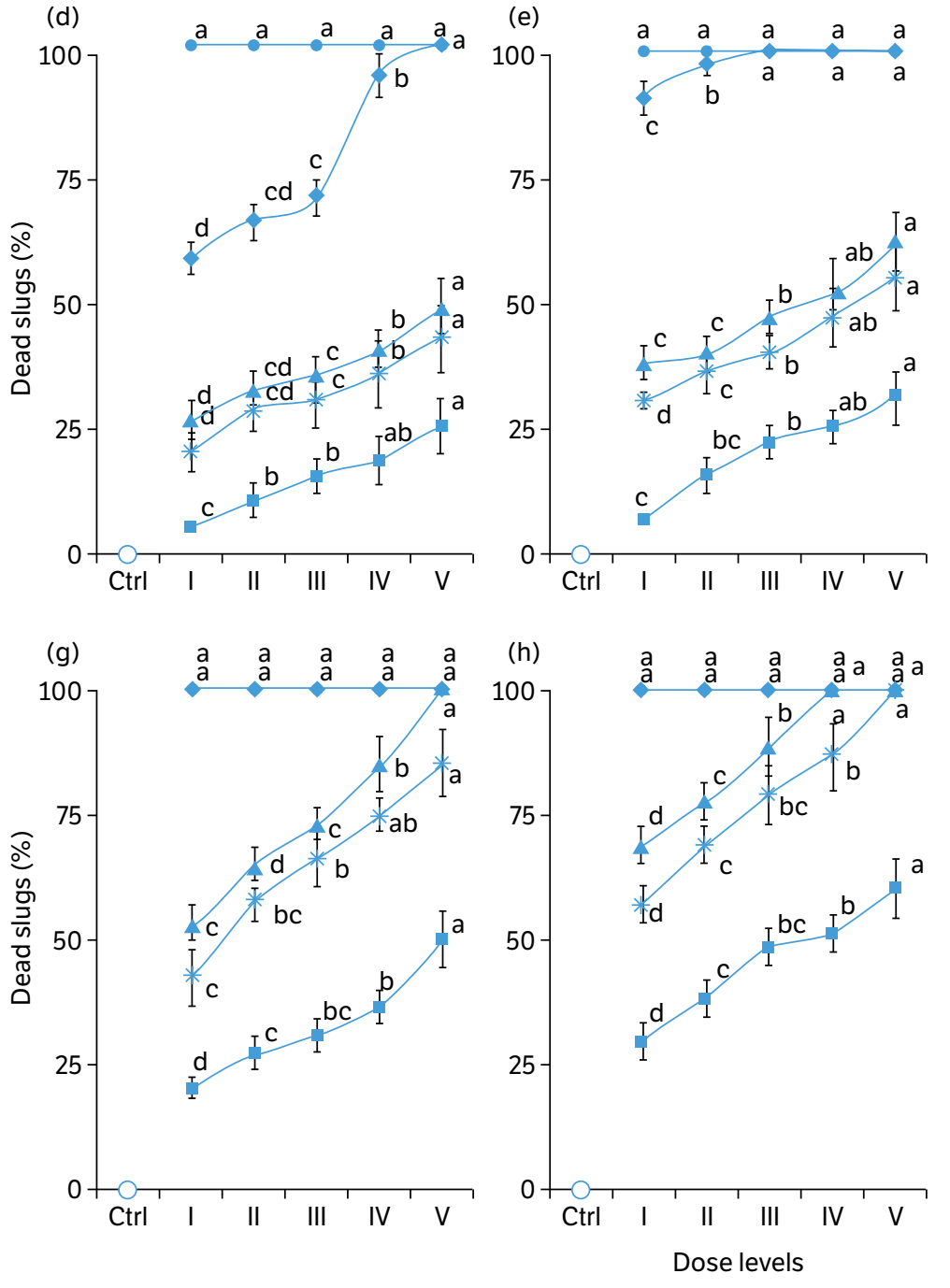

(c)
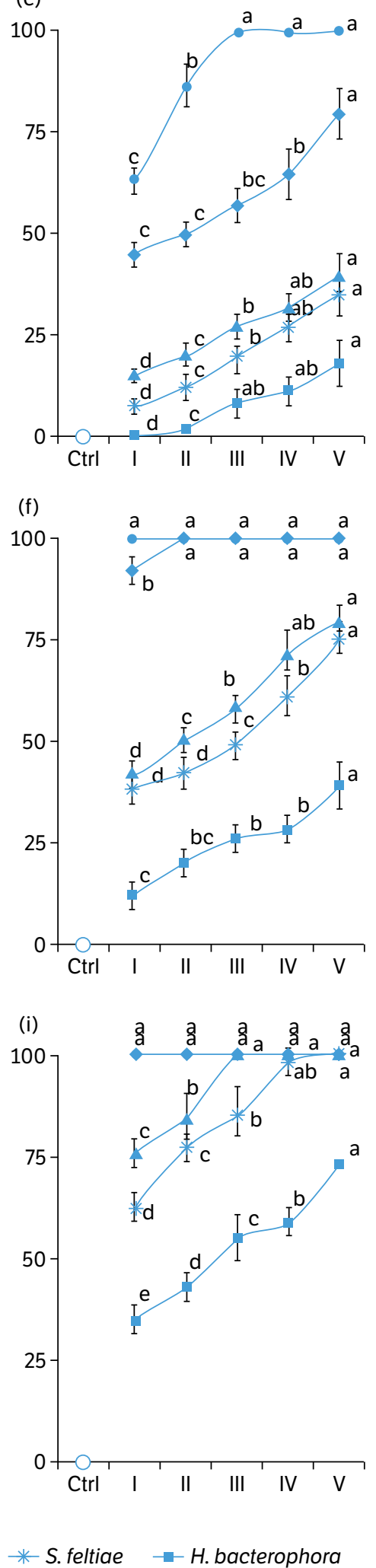

Figure 1. Population mortality rate (\%) of the slug Parmacella ibera under metaldehyde, P. hermaphrodita, S. carpocapsae, S. feltiae and $H$. bacteriophora treatments at dose levels and exposure times.

The letters a, b, c, d, e, f, g, h and i correspond to days 1, 2, 3, 4, 5, 6, 7, 8 and 9, as exposure times, respectively. Defined doses at the X axes (I, II, III, IV and V) respectively correspond to $250,500,1000,2000$ and $4000 \mathrm{IJs} \cdot \mathrm{qm}^{-2}$ for the nematodes; and $1,2,4,8$ and $16 \mathrm{~g} \cdot \mathrm{m}^{-2}$ for the molluscicide metaldehyde. Means with the same letters on the curves are not significantly different $(p<0.05 ; n=5)$. 
The results of the seedlings establishment assay showed that, EPNs caused a significant $(\mathrm{p}<0.05)$ increase in the rate of the established plants. Increasing the dose levels of nematodes and pesticide improved the number of the established plants. The most established plants rate was found in metaldehyde (90.5\%, dose V, day 8), P. hermaphrodita (79.6\%, dose V, day 6), S. carpocapsae (35.8\%, dose V, day 6), S. feltiae (17.1\%, dose V, day 8) and H. bacteriophora (8.7\%, dose V, day 2) treatments (Fig. 3).

\section{DISCUSSION}

The results of the current study are consistent with the findings of some research (Genena and Mostafa 2013; El-Ashry and Abd El-Aal 2019). Genena and Mostafa (2013) evaluated the molluscicide effect of P. hermaphrodita, H. bacteriophora, S. carpocapsae and Diplogaster spp. at three levels (2000, 5000 and $\left.7500 \mathrm{IJ} \mathrm{s}^{\cdot} \mathrm{cm}^{-2}\right)$ on the clover land snail Monacha cantiana in 1-3 weeks of exposure times. Phasmarhabditis hermaphrodita was the most effective nematode on the snail, followed by
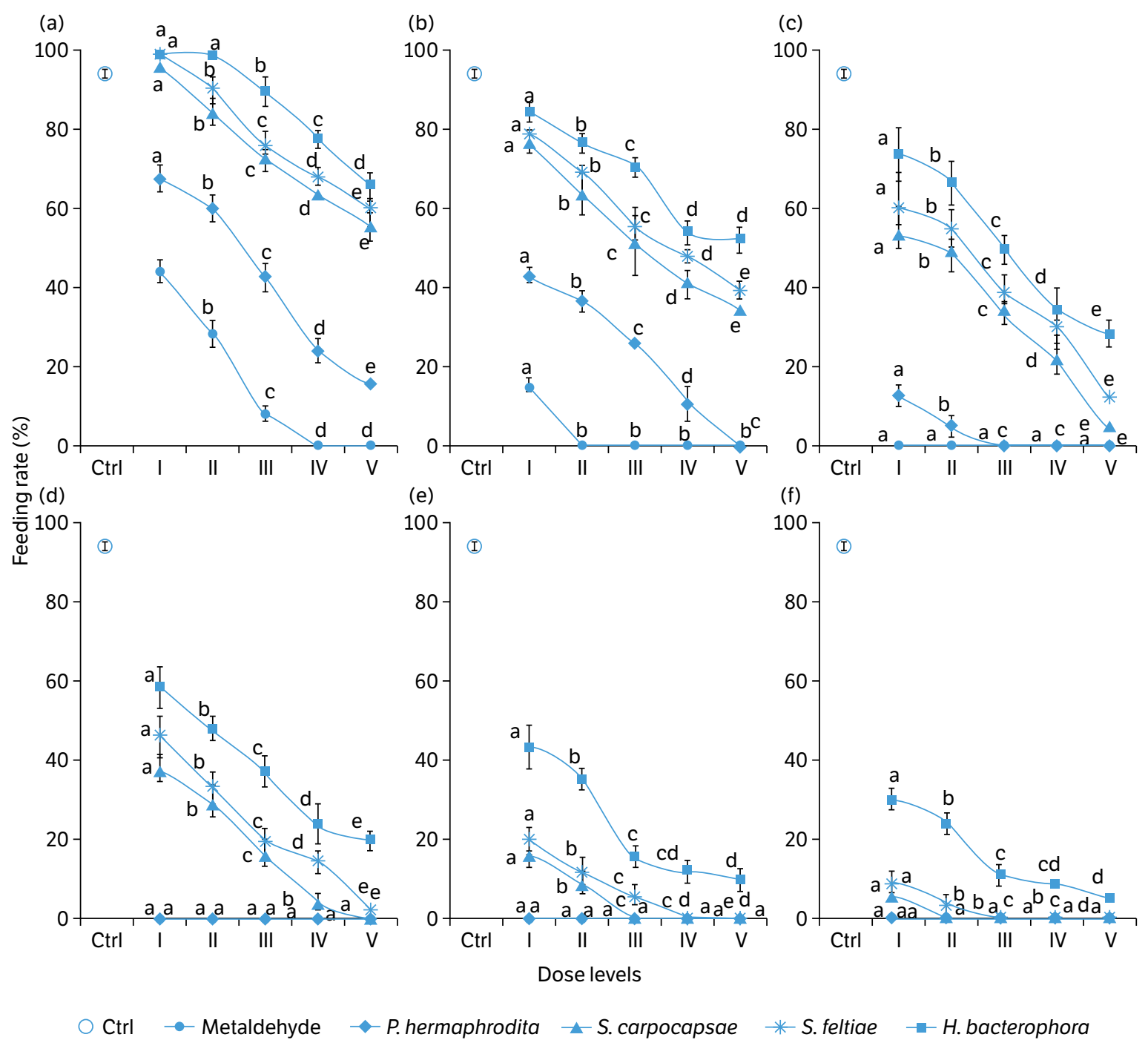

Figure 2. Feeding rate (\%) of the slug Parmacella ibera under metaldehyde, P. hermaphrodita, S. carpocapsae, S. feltiae and H. bacteriophora treatments at dose levels and exposure times.

The letters a, b, c, d, e and f correspond to days 1, 2, 3, 4, 5 and 6, as exposure times, respectively. Defined doses at the X axes (I, II, III, IV and V) respectively correspond to $250,500,1000,2000$ and $4000 \mathrm{IJs} \cdot \mathrm{m}^{-2}$ for the nematodes; and 1, 2, 4, 8 and $16 \mathrm{~g} \cdot \mathrm{m}^{-2}$ for the molluscicide metaldehyde. Means with the same letters on the curves are not significantly different $(p<0.05 ; n=5)$. 
Diplogaster spp., H. bacteriophage and S. carpocapsae with a mortality rate of 73, 30, 20 and 13\%, respectively, after three weeks of treatment (Genena and Mostafa 2013). Also, El-Ashry and Abd El-Aal (2019) found that S. carpocapsae and H. bacteriophora had a lethal effect on the populations of D. resticulatum and D. laeve in vitro. S. carpocapsae showed the highest level of mortality on D. laeve and D. reticulatum after 14 days at $2000 \mathrm{IJs}^{\cdot} \mathrm{cm}^{-2}$, while the use of $H$. bacteriophora resulted in mortality of 50 and $66.67 \%$ in D. laeve and D. reticulatum, respectively.

These positive results have not been repeated in other studies; for example, in a laboratory study, the EPNs S. feltiae or H. megidis had no pathogenic effect on the slug D. reticulatum (Wilson et al. 1994). Following the results of the study by Genena and Mostafa (2013) and El-Ashry and Abd El-Aal (2019), the current experiment indicated that all three species of EPNs, S. carpocapsae, S. feltiae and H. bacteriophora were capable to parasitize the slug $P$. ibera, and caused its population mortality. Meanwhile, the fatality sufficiency of $H$. bacteriophora was relatively minor, especially in low levels of dose and exposure time; while species belonging to the genus Steinernema, especially S. carpocapsae, showed an acceptable control on the slugs population. Wilson et al. (1994) studied the capability of the EPNs S. feltiae (UK 76) and H. sp. (North West

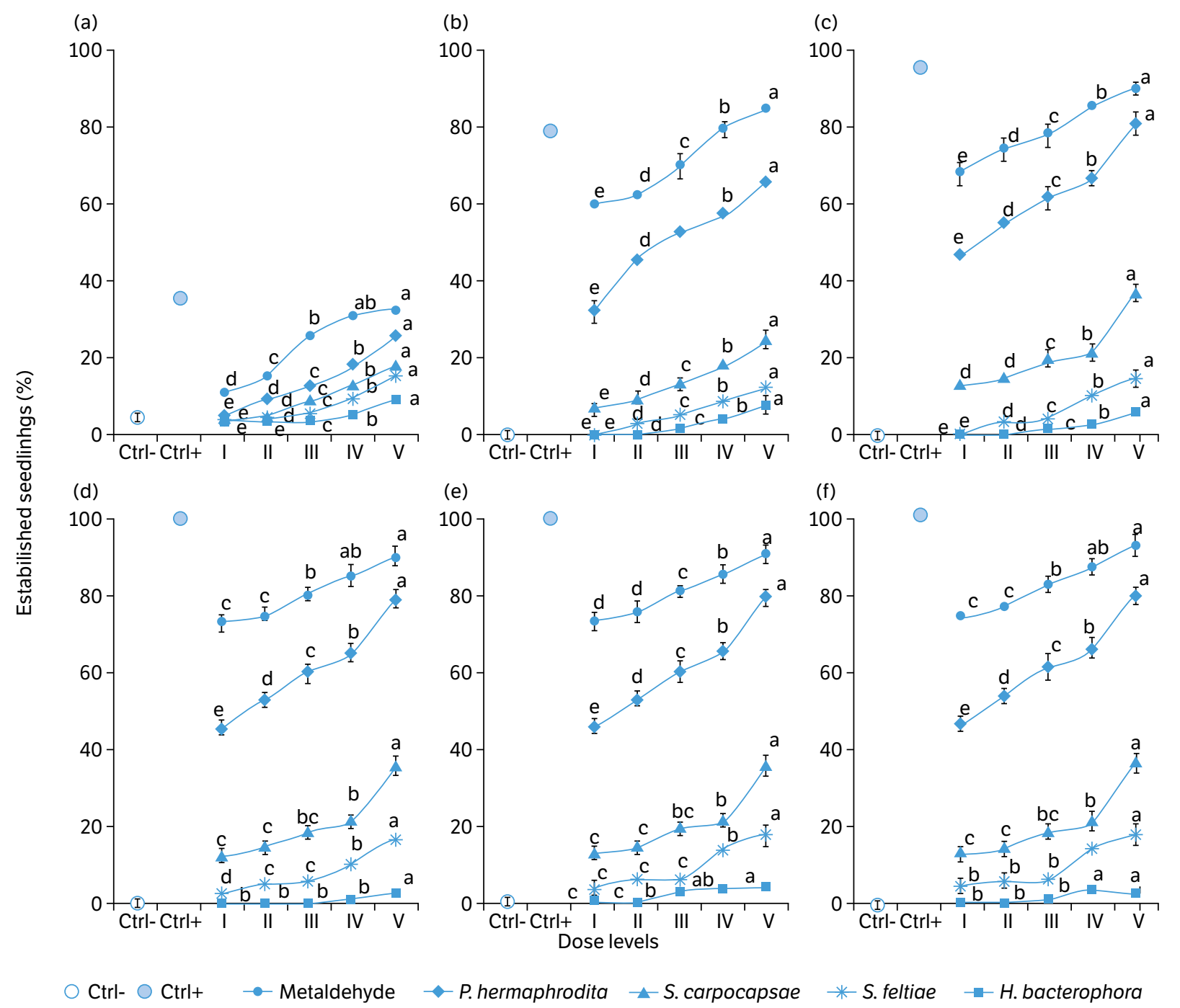

Figure 3. Established seedlings (\%) of exposed to the slug Parmacella ibera under metaldehyde, P. hermaphrodita, S. carpocapsae, S. feltiae and $H$. bacteriophora treatments at dose levels and exposure times.

The letters a, b, c, d, e and f correspond to days 2, 4, 6, 8, 10 and 12, as exposure times, respectively. Dose levels I, II, III, IV and V correspond to 250, 500, 1000, 2000 and $4000 \mathrm{IJs} \cdot \mathrm{m}^{-2}$ for the nematodes; and $1,2,4,8$ and $16 \mathrm{~g} \cdot \mathrm{m}^{-2}$ for metaldehyde, respectively. Ctrl correspond to the treatment including the slug and without the control agents; the containers free of the slug and the control agents was considered as Ctrl+. Means with the same letters on the curves are not significantly different $(p<0.05 ; n=5)$. 
European Group, UK 211), and the SPN P. hermaphrodita (UK 1) to control the slug D. reticulatum in soil and Petri dish bioassays. They found that these EPNs cannot kill the slug in both bioassays performed at 14 and $23^{\circ} \mathrm{C}$. Although, Xenorhabdus bovienii and Photorhabdus luminescens, (the symbiotic bacteria of S. feltiae and Heterorhabditis sp., respectively) were also injected into a number of slugs, but the symptoms of the disease were not observed in the slugs population. Vice versa, the SPN controlled the slug at $14^{\circ} \mathrm{C}$ but not at $23^{\circ} \mathrm{C}$. However, the results of the current study indicated that, the EPNs played a significant role in reducing the population and the nutrition of the slug $P$. ibera. The difference in results can be attributed to different strains of EPNs and especially various host slug species.

Host species has been effective on fatality rate of mollusc parasitic nematodes. Studies have indicated that $P$. hermaphrodita affects several species of slug and snail (De Ley et al. 2014; Genena and Mostafa 2013; Wilson et al. 2012), among which the effect of the nematode on slug D. reticulatum has been very significant (El-Danasoury and Iglesias-Piñeiro 2017). The SPN $P$. hermaphrodita has sometimes failed to control the slugs, for example, Speiser et al. (2001) found that $P$. hermaphrodita does not have much lethal effect on the Spanish big slugs, whereas the results of current research showed that the SPN caused $100 \%$ mortality rate (dose V, day 4 ) on $P$. ibera population.

The ability of EPNs to affect and eliminate host pest depends on a number of factors including the type of nematodehost relationship, host specialty, physiology of parasitism, and hostility resistance (Poinar Junior and Grewal 2012). The EPN S. carpocapsae has the widest range of hosts in the EPNs. This nematode has been infected and reproduced on more than 250 insect species in vitro (Grewal et al. 2005). In the hosting domain, S. feltiae, H. bacteriophora and P. hermaphrodita are located at subsequent levels, respectively. Phasmarhabditis hermaphrodita has not been isolated from any insect. The host range of $P$. hermaphrodita seems to be limited to the terrestrial molluscs, slugs, and snails (Ester et al. 2003).

The results of the current study indicated that $P$. hermaphrodita was more successful regarding the mortality and control of the slugs population compared to S. carpocapsae, S. feltiae and H. bacteriophora. Considering obvious differences between the anatomy and physiology of slugs and insects, obtaining such results was not unexpected. Seemingly, P. hermaphrodita has caused more infection and mortality than the EPNs on the slugs population by being compatible with the anatomical, biological, and physiological traits of slugs. Increasing rainfall, presence of dew and free moisture on plant organs, and low air velocity are effective factors in the enhancement of slugs' activity. Also, slugs' activity has been developed under conditions of light soils with organic matter, coarse grains of soil and presence of pores and cracks in soil texture, presence of shadow in the field and high plant density, reduced tillage operations and presence of herbal residue in field, and the lack of natural enemies including birds (Choi et al. 2006; Mensink and Henry 2011).

The findings of the current study, as well as other similar studies, showed that the SPN P. hermaphrodita had the greatest suppressive effect on the population of the slug (Ester et al. 2003; Hapca et al. 2007; Richards et al. 2008; Rae et al. 2009), and the EPNs $S$. carpocapsae, S. feltiae and H. bacteriophora ranked next, respectively.

The use of commercial isolate of $P$. hermaphrodita has led to a decrease in grazing of $D$. reticulatum in experimental clover fields in New Zealand, so that the recommended dose of this nematode increased the density of clover even in the high population of the slug. The slugs population was high enough for the clovers to be consumed almost entirely by the slugs in untreated controls. In spite of the presence of slugs, using the nematode in treatments increased plant establishment (Wilson et al. 2012). In the current study, the plant establishing rate (\%) was higher in the EPNs treatments than control (no nematode no pesticide). Following metaldehyde and $P$. hermaphrodita, the highest number of established plants was observed in S. carpocapsae, S. feltiae and $H$. bacteriophora treatments, respectively. Although, it was a relatively long time between the onset of slug infection to nematode and slug death (more than a week), but infected slugs were fed less during the period of infection (Glen et al. 2000). However, control effects of EPNs on the mollusc populations were not confirmed in field condition (Wilson 2007).

Providing a permanent pest management and establishing a balance between pest populations and their biocontrol agents is the key to a successful biological pest control. However, the success of biological control relies on a wide range of environmental parameters, and its complex interactions made it difficult to predict management conditions. Hence, Wilson et al. (2000) believed that using biological control for controlling a pest has been raised as a long game, rather than a quickfire solution. Currently, slug control is highly dependent on chemical methods; nevertheless, the present study showed that, in addition to SPN, EPNs were also able to control the slug P. ibera in vitro and in greenhouse condition, and can be a good alternative to chemical pesticides. 


\title{
CONCLUSION
}

The EPNs can have a control effect on the slug $P$. ibera, so that the most suppressive level was obtained on population, nutrition and damage of the pest in S. carpocapsae, S. feltiae and H. bacteriophora treatments, respectively, at different levels of dosage and in vitro exposure time.

\section{FUNDERS}

\author{
Shahed University
}

Grant \#9407.6

\section{AUTHOR'S CONTRIBUTION}

Conceptualization: Saeedizadeh A.; Methodology: Saeedizadeh A. and Niasti F.; Investigation: Saeedizadeh A.; WritingOriginal Draft: Saeedizadeh A.; Writing - Review and Editing: Saeedizadeh A. and Niasti F.; Funding Acquisition: Saeedizadeh A.; Resources: Saeedizadeh A.; Supervision: Saeedizadeh A.

\section{REFERENCES}

Abd-Elgawad, M. M. M., Askary, T. H. and Coupland, J. (2017). Biocontrol agents: entomopathogenic and slug parasitic nematodes. Wallingford: CABI. https://doi.org/10.1079/9781786390004.0000

Al-Sarar, A., Hussein, H., Abobakr, Y. and Bayoumi, A. (2012). Molluscicidal activity of methomyl and cardenolide extracts from Calotropis procera and Adenium arabicum against the land snail Monacha cantiana. Molecules, 17, 5310-5318. https://doi.org/10.3390/ molecules17055310

Azarnia, S., Abbasipour, H., Saeedizadeh, A. and Askarianzadeh, A. (2018). Laboratory assay of entomopathogenic nematodes against clearwing moth (Lepidoptera: Sesiidae) larvae. Journal of Entomological Science, 53, 62-69. https://doi.org/10.18474/JES17-28.1

Birah, A., Chilana, P., Shukla, U. K. and Gupta, G. P. (2008). Mass rearing of greater wax moth (Galleria mellonella L.) on artificial diet. Indian Journal of Entomology, 70, 389-392.

Castle, G. D., Mills, G. A., Gravell, A., Jones, L., Townsend, I., Cameron, D. G. and Fones, G. R. (2017). Review of the molluscicide metaldehyde in the environment. Environmental Science: Water Research \& Technology, 3, 415-428. https://doi.org/10.1039/C7EW00039A

Choi, Y. H., Bohan, D. A., Potting, R. J. P., Semenov, M. A. and Glen, D. M. (2006). Individual based model of slug population and spatial dynamics. Ecological Modelling, 190, 336-350. https://doi.org/10.1016/j.ecolmodel.2005.04.019

Damalas, C. A. and Koutroubas, S. D. (2018). Current status and recent developments in biopesticide use. Agriculture, 8, 13. https://doi. org/10.3390/agriculture8010013

De Ley, I. T., McDonnell, R. D., Lopez, S., Paine, T. D. and De Ley, P. (2014). Phasmarhabditis hermaphrodita (Nematoda: Rhabditidae), a potential biocontrol agent isolated for the first time from invasive slugs in North America. Nematology, 16, 1129-1138. https://doi. org/10.1163/15685411-00002838

Dutky, S. R., Thompson, J. V. and Cantwell, G. E. (1964). A technique for the mass propagation of the DD-136 nematode. Journal of Insect Pathology, 6, 417-422. 
El-Ashry, R. M. and Abd El-Aal, E. M. (2019). Evaluation of certain Egyptian Heterorhabditids isolates as molluscicidal nematodes for the control of Deroceras reticulatum and D. laeve slugs under laboratory conditions. Egyptian Journal of Agronematology, $18,70-80$. https://doi.org/10.21608/ejaj.2019.52596

El-Danasoury, H. and Iglesias-Piñeiro, J. (2017). Performance of the slug parasitic nematode Phasmarhabditis hermaphrodita under predicted conditions of winter warming. Journal of Pesticide Science, 42, 62-66. https://doi.org/10.1584/jpestics.D16-097

Ester, A., Rozen, K. V. and Molendijk, L. P. G. (2003). Field experiments using the rhabditid nematode Phasmarhabditis hermaphrodita or salt as control measures against slugs in green asparagus. Crop Protection, 22, 689-695. https://doi.org/10.1016/S0261-2194(03)00003-6 Foltan, P. (2004). Influence of slug defence mechanisms on the prey preferences of the carabid predator Pterostichus melanarius (Coleoptera: Carabidae). European Journal of Entomology, 101, 359-364. https://doi.org/10.14411/eje.2004.050

Genena, M. A. M. and Mostafa, F. A. M. (2013). Pathogenicity of Phasmarhabditis hermaphrodita, Heterorhabditis bacteriophora, Steinernema carpocapsae and Diplogaster spp. against the clover land snail, Monacha cantiana. World Research Journal of Agricultural Biotechnology, 2, 17-20.

Glen, D. M., Wilson, M. J., Brain, P. and Stroud, G. (2000). Feeding activity and survival of slugs, Deroceras reticulatum, exposed to the rhabditid nematode, Phasmarhabditis hermaphrodita: a model of dose response. Biological Control, 17, 73-81. https://doi.org/10.1006/ bcon.1999.0778

Grewal, P. S., Ehlers, R. U. and Shapiro-llan, D. I. (2005). Nematodes as biocontrol agents. Wallingford: CABI. https://doi. org/10.1079/9780851990170.0000

Hapca, S., Crawdford, J., Rae, R., Wilson, M. and Young, I. (2007). Movement of the parasitic nematode Phasmarhabditis hermaphrodita in the presence of mucus from the host slug Deroceras reticulatum. Biological Control, 41, 223-229. https://doi.org/10.1016/j.biocontrol.2007.01.005

Kozłowski, J., Jaskulska, M., Kałuski, T. and Kozlowska, M. (2011). The effect of temperature and humidity on the grazing activity of Deroceras reticulatum (O. F. Müller, 1774) and the damage to rape plants. Folia Malacologica, 19, 267-271. https://doi.org/10.2478/v10125-011-0017-4 Mensink, P. J. and Henry, H. A. L. (2011). Rain events influence short-term feeding preferences in the snail Cepaea nemoralis. Journal of Molluscan Studies, 77, 241-247. https://doi.org/10.1093/mollus/eyr011.

Poinar Junior, G. O. and Grewal, P. S. (2012). History of entomopathogenic nematology. Journal of Nematology, 44, $153-161$.

Rae, R. (2017). The gastropod shell has been co-opted to kill parasitic nematodes. Scientific Reports, 7, 4745. https://doi.org/10.1038/ s41598-017-04695-5.

Rae, R. G., Robertson, J. F. and Wilson, M. J. (2009). Chemoattraction and host preference of the gastropod parasitic nematode Phasmarhabditis hermaphrodita. Journal of Parasitology, 95, 517-526. https://doi.org/10.1038/s41598-017-04695-5

Richards, E. H., DeMarzo, D., Port, G. R., Dani, M. P. and Walters, K. F. A. (2008). Effects of the nematode Phasmarhabditis hermaphrodita and of venom from the endoparasitic wasp Pimpla hypochondriaca on survival and food consumption of the pest slug Deroceras reticulatum; implications for novel biocontrol strategies. Pest Management Science, 64, 711-719. https://doi.org/10.1002/ps.1546

Speiser, B., Zaller, J. G. and Neudecker, A. (2001). Size-specific susceptibility of the pest slugs Deroceras reticulatum and Arion Iusitanicus to the nematode biocontrol agent Phasmarhabditis hermaphrodita. BioControl, 46, 311-320. https://doi.org/10.1023/A:1011469730322

Watts, A. (2012). Rain brings slug invasion. Farmers Weekly [Internet]. [Accessed July 17, 2012]. Available at: https://www.fwi.co.uk/ arable/rain-brings-slug-invasion.

White, G. F. (1927). A method for obtaining infective nematode larvae from cultures. Science, 66, 302-303. https://doi.org/10.1126/ science.66.1709.302-a 
Wilson, M. J., Glen, D. M., George, S. K., Pearce, J. D. and Wiltshire, C. W. (1994). Biological control of slugs in winter wheat using the rhabditid nematode Phasmarhabditis hermaphrodita. Annals of Applied Biology, 125, 377-390. https://doi.org/10.1111/j.1744-7348.1994. tb04978.x

Wilson, M. J., Hughes, L. A., Hamacher, G. M. and Glen, D. M. (2000). Effects of Phasmarhabditis hermaphrodita on non-target molluscs. Pest Management Science, 56, 711-716. https://doi.org/10.1002/1526-4998(200008)56:8<711::AID-PS185>3.0.CO;2-O

Wilson, M. J. (2007). Terrestrial mollusc pests. In L. A. Lacey and H. K. Kaya (Eds.), Field manual of techniques in invertebrate pathology. (p. 751-765). Dordrecht: Springer.

Wilson, M. J. and Barker, G. M. (2010). Slugs as pasture pests. Grassland research and practice series, 15, 125-128.

Wilson, M. J. and Barker, G. M. (2011). Slugs as pasture pests. Proceedings of the New Zealand Grassland Association, 72, $241-246$.

Wilson, M. J., Burch, G., Tourna, M., Aalders, L. T. and Barker, G. M. (2012). The potential of a New Zealand strain of Phasmarhabditis hermaphrodita for biological control of slugs. New Zealand Plant Protection, 65, 161-165. https://doi.org/10.30843/nzpp.2012.65.5388

Yakhchali, M., Gorgani-Firuzjaei, T. and Baghri, K. (2013). Radular teeth morphology in Limax (Caspilimax) keyserlingi (Martens, 1880) and Parmacella ibera (Eichwald, 1841) from Northern Iran. Iranian Journal of Parasitology, 8, 256-263.

Zolfagharian, M., Saeedizadeh, A. and Abbasipour, H. (2016). Efficacy of two entomopathogenic nematode species as potential biocontrol agents against the diamondback moth, Plutella xylostella (L.). Journal of Biological Control, 30, 78-83. https://doi. org/10.18311/jbc/30/2/14919

In the article Response of grey slug to entomopathogenic nematodes with DOI: https://doi.org/10.1590/1678-4499.20200107, published in Bragantia vol.79 no.4 Campinas Oct./Dec. 2020:

In the footline where is read Bragantia, Campinas, v. 79, n. 4, p.447-456, 2020 should be read Bragantia, Campinas, v. 79, n. 4, p.572-581, 2020. 